\title{
Lipid Raft Destabilization Impairs Mouse TRPA1 Responses to Cold and Bacterial Lipopolysaccharides
}

\author{
Justyna B. Startek and Karel Talavera * (C) \\ Laboratory of Ion Channel Research, Department of Cellular and Molecular Medicine, KU Leuven; VIB Center \\ for Brain \& Disease Research, Herestraat 49, Campus Gasthuisberg O\&N1 bus 802, 3000 Leuven, Belgium; \\ justyna.startek@kuleuven.vib.be \\ * Correspondence: karel.talavera@kuleuven.vib.be; Tel.: +32-1633-0469
}

Received: 11 August 2019; Accepted: 27 May 2020; Published: 28 May 2020

\begin{abstract}
The Transient Receptor Potential ankyrin 1 cation channel (TRPA1) is expressed in nociceptive sensory neurons and epithelial cells, where it plays key roles in the detection of noxious stimuli. Recent reports showed that mouse TRPA1 (mTRPA1) localizes in lipid rafts and that its sensitivity to electrophilic and non-electrophilic agonists is reduced by cholesterol depletion from the plasma membrane. Since effects of manipulating membrane cholesterol levels on other TRP channels are known to vary across different stimuli we here tested whether the disruption of lipid rafts also affects mTRPA1 activation by cold or bacterial lipopolysaccharides (LPS). Cooling to $12{ }^{\circ} \mathrm{C}$, E. coli LPS and allyl isothiocyanate (AITC) induced robust $\mathrm{Ca}^{2+}$ responses in CHO-K1 cells stably transfected with mTRPA1. The amplitudes of the responses to these stimuli were significantly lower in cells treated with the cholesterol scavenger methyl $\beta$-cyclodextrin (MCD) or with the sphingolipids hydrolyzer sphingomyelinase (SMase). This effect was more prominent with higher concentrations of the raft destabilizers. Our data also indicate that reduction of cholesterol does not alter the expression of mTRPA1 in the plasma membrane in the CHO-K1 stable expression system, and that the most salient effect is that on the channel gating. Our findings further indicate that the function of mTRPA1 is regulated by the local lipid environment and suggest that targeting lipid-TRPA1 interactions may be a strategy for the treatment of pain and neurogenic inflammation.
\end{abstract}

Keywords: mouse TRPA1; cholesterol; sphingolipids; lipid rafts; LPS; cold

\section{Introduction}

Biological membranes are dynamic and complex lipid-protein systems, forming a protective boundary around the cell and participating in multiple physiological processes [1]. Lipid bilayers, made out of two opposing leaflets, contain multiple, asymmetrically distributed lipids that belong to three classes: glycerophospholipids, sphingolipids and sterols [2,3]. High concentrations of sterols such as cholesterol, induce conformational ordering of the hydrocarbon chains of other lipids, resulting in stiffening and reduced permeability of the membrane [4]. In contrast, cholesterol depletion significantly increases the bilayer permeability and affects the conformation and activities of membrane proteins [5]. Cholesterol influences the membrane thickness and fluidity, as well as the organization of membrane domains, such as lipid rafts [6]. Lipid rafts are small, highly dynamic signaling platforms that support correct localization and function of many proteins. This seems to be particularly important for sensory signaling, as the modification of the cholesterol content at the plasma membrane alters the function of several sensory Transient Receptor Potential (TRP) cation channels [7-12]. One of these proteins, the ankyrin-rich TRPA1, is arguably the most versatile polymodal sensor, being activated by thermal [13-22] and mechanical [15,23-27] stimuli, and by an impressive variety of chemicals [28-30]. 
We recently showed that mouse mTRPA1 localizes mainly in cholesterol rich domains and that disruption of lipid rafts changes the expression pattern of this protein from an extended distribution along the plasma membrane to well-defined clusters [31]. Our data also indicated that mTRPA1 channels could directly interact with cholesterol through cholesterol recognition amino acid consensus (CRAC) motifs located in TM2 and TM4 domains of the channel. Mutation of specific amino acids in these motifs reduces mTRPA1 responses to AITC and decreases the expression of the channel in the plasma membrane [31]. Thus, direct cholesterol-mTRPA1 interactions seem to be necessary for normal channel gating and targeting to the membrane specific subdomains [31]. These findings led us to propose that, together with the other key polymodal nociceptive channel TRPV1 [12], mTRPA1 forms signaling complexes in membrane microdomains, which support direct protein-protein interactions and/or $\mathrm{Ca}^{2+}$-dependent crosstalk.

One of the questions generated by our previous study is whether alterations in cholesterol and sphingolipid levels influence the responses of TRPA1 to other types of stimuli. This question does not have an obvious answer, because the influence of cholesterol manipulations on TRP channel function has been shown to be complex. For example, cholesterol depletion was reported not to affect the thermal sensitivity of TRPV1 [7], but later shown to reduce the amplitude of currents activated by capsaicin and protons [8]. In this report, we show that lipid raft disruption reduces the responses of mTRPA1 to cold [14] and bacterial lipopolysaccharides [32,33]. Our findings further support the hypotheses that mTRPA1 function strongly depends on the local lipid environment and suggest that lipid-TRPA1 interactions could be also used as therapeutic targets for the treatment of pain and neurogenic inflammation.

\section{Results}

\subsection{Cholesterol Depletion Reduces mTRPA1 Response to Cold}

We used ratiometric $\mathrm{Ca}^{2+}$ imaging to examine the responses of $\mathrm{CHO}-\mathrm{K} 1$ cells stably expressing mTRPA1 to cold in control or after pretreatment with 1,5 or $10 \mathrm{mM}$ methyl $\beta$-cyclodextrin (MCD). The responses were analyzed in terms of maximal amplitude of the change in intracellular $\mathrm{Ca}^{2+}$ concentration $\left(\Delta\left[\mathrm{Ca}^{2+}\right]\right)$. We also measured the maximal first time derivative (rising rate) of intracellular $\mathrm{Ca}^{2+}$ responses, $\left(\mathrm{d}\left[\mathrm{Ca}^{2+}\right] / \mathrm{dt}\right)_{\mathrm{MAX}}$, which is more directly related to the currents carried by the mTRPA1 channels. Control cells responded with an increase in intracellular $\mathrm{Ca}^{2+}$ concentration upon application of cooling solution $\left(12{ }^{\circ} \mathrm{C}\right.$; Figure 1a). Neither $\Delta\left[\mathrm{Ca}^{2+}\right]$ or $\left(\mathrm{d}\left[\mathrm{Ca}^{2+}\right] / \mathrm{dt}\right)_{\mathrm{MAX}}$ of the responses to cold followed a normal distribution, as the majority of cells displayed relatively small and slow responses, resulting in a mismatch between the median and the average values (Figure 1c,e). A subsequent application of $100 \mu \mathrm{M}$ AITC triggered very robust $\mathrm{Ca}^{2+}$ responses $(>500 \mathrm{nM})$ in the majority of cells (Figure 1a,d), and the corresponding distribution of amplitudes was approximated by a normal distribution (see the match between the mean and median values in Figure 1d).

Cells pretreated with $1 \mathrm{mM}$ MCD responded to cooling with amplitudes similar to those of control cells, but cells pretreated with $5 \mathrm{mM}$ or $10 \mathrm{mM}$ MCD responded with significantly smaller amplitudes (Figure 1b,c). A reduction of the maximal values of the first derivative was already apparent from 1 $\mathrm{mM} \mathrm{MCD}$ and was stronger at 5 and $10 \mathrm{mM}$ (Figure 1e). As expected from our previous study [31], the MCD treatments also decreased the amplitude and maximal rising rate of responses to the TRPA1 electrophilic agonist AITC [34,35] (Figure 1b,d,f). 
a

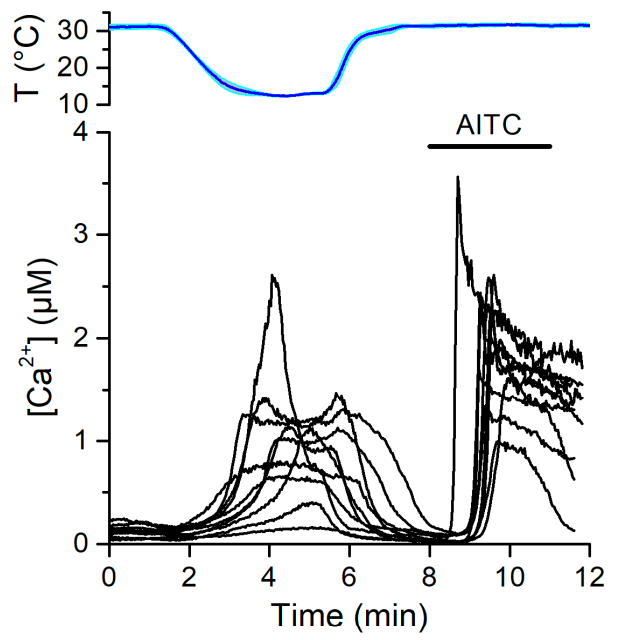

C
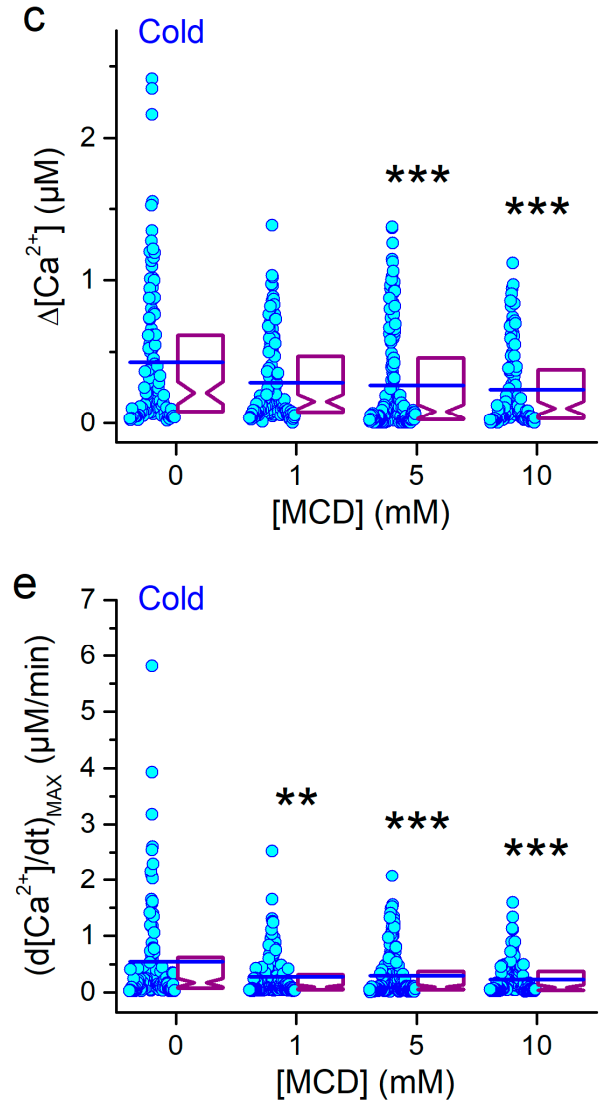

b

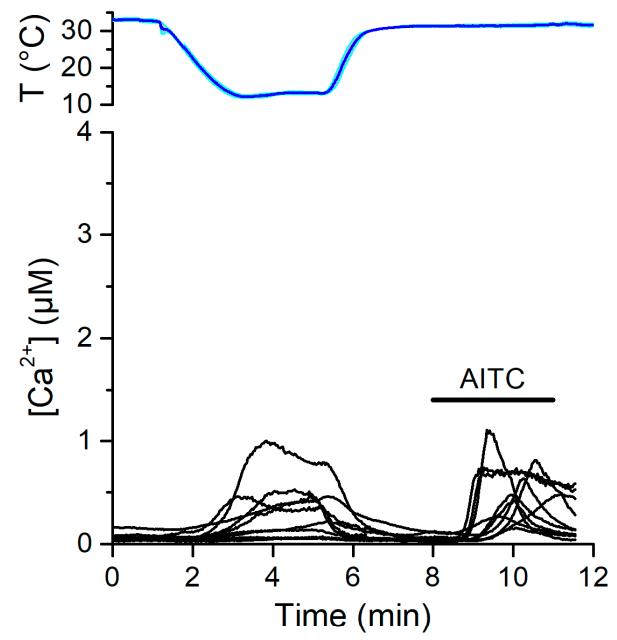

d
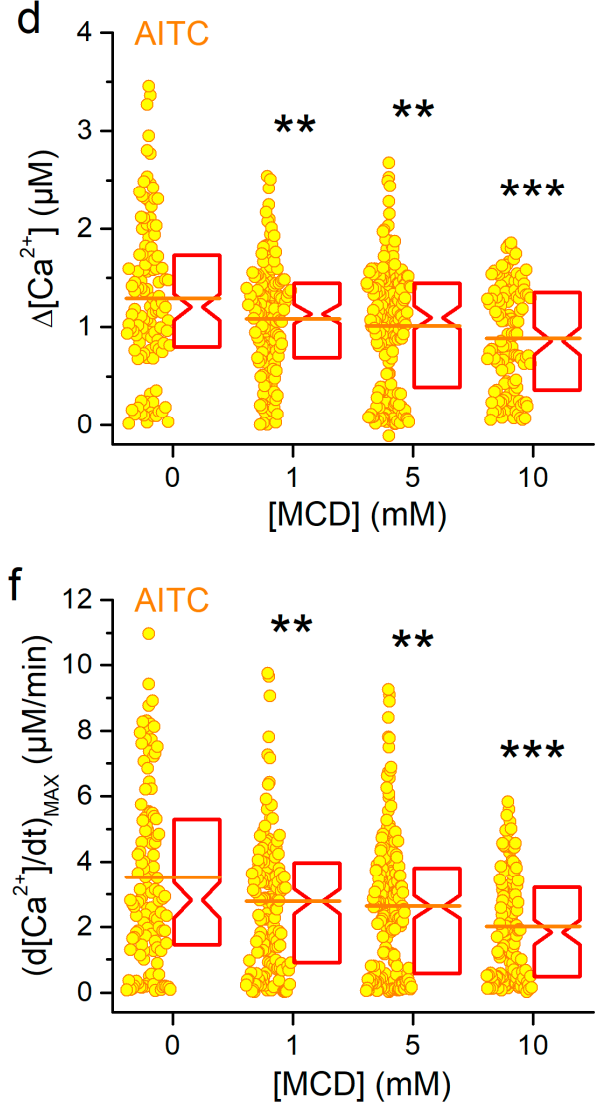

Figure 1. Effects of cholesterol depletion on cold-induced responses of mTRPA1. (a and $\mathbf{b})$ Representative traces of $\left[\mathrm{Ca}^{2+}\right]$ change induced by cooling (upper panels) in the control condition (a) and after pretreatment with $10 \mathrm{mM}$ MCD (b). Application of AITC $(100 \mu \mathrm{M})$ was used as control for mTRPA1 activation. (c and d) Amplitudes of $\left[\mathrm{Ca}^{2+}\right]$ responses evoked by cold (c) and AITC (d) in control condition $(n=118)$ or after pretreatment with $1(n=149), 5(n=202)$ or $10 \mathrm{mM}(n=130)$ of MCD. (e and $\mathbf{f}$ ) Maximal amplitudes of the first time derivative of the intracellular $\mathrm{Ca}^{2+}$ signal elicited by cold (e) and AITC (f) in control condition or after treatment with 1, 5 or $10 \mathrm{mM}$ of MCD (the $n$ numbers are the same as in panels $\mathrm{c}$ and d). The symbols ${ }^{*}{ }^{* *}$ and ${ }^{* * *}$ indicate $p<0.05, p<0.01$ and $p<0.001$, respectively; Kolmogorov-Smirnov test.

Next, we aimed at evaluating whether cholesterol depletion alters the response of mTRPA1 channels to cold, independently of an eventual effect on channel expression at the plasma membrane [31]. A 
way to do this could be normalizing the response of each cell to cold by its response to AITC. If the normalized amplitudes are changed by increasing MCD concentrations, this would mean that there is a direct effect of cholesterol depletion on channel gating. However, this method would be appropriate only if the amplitudes of the responses to cold are strictly correlated to the amplitudes of the responses to AITC across the cell population for control and all MCD pretreatment conditions. We found that in control cells the amplitudes of the responses to cold and AITC showed some degree of correlation (Pearson's correlation coefficient, $R=0.72$ ). However, the correlation was low in cells treated with $\operatorname{MCD}(R=0.41,0.54$ and 0.20 , for MCD 1, 5 and $10 \mathrm{mM}$, respectively). These observations are consistent with the weak action of these stimuli in cells treated with MCD [36]. Another way to contrast the effects of cholesterol depletion on cold- and AITC-induced responses is to compare the levels of statistical significance of the effects of the MCD treatments (Figure 1c-f). These indicate that the sensitivities of the responses to cold and AITC to the MCD treatments were rather similar.

To further investigate mTRPA1 activation after disruption of lipid rafts, we treated the cells with sphingomyelinase (SMase). This enzyme hydrolyzes sphingomyelin (SM), which is one of the components of lipid rafts and roughly constitutes $2 \%-15 \%$ of total lipids of cellular membranes $[37,38]$. SM hydrolysis triggers the formation of ceramide and phosphocholine, inducing an increase in the membrane tension [38,39]. An intermediate response to the bilayer ordering is release of cholesterol and further reorganization of the lipid rafts [40]. Treatment of cells with SMase reduced the amplitude as well as the maximal rising rate of the response to cold in a concentration dependent manner (12 ${ }^{\circ} \mathrm{C}$; Figure $\left.2 \mathrm{a}-\mathrm{c}, \mathrm{e}\right)$. Additionally, the amplitude and the maximal rising rate of responses to AITC application were reduced by SMase (Figure 2b,d,f), as predicted from our previous report [31].

Like for the MCD treatment, the levels of statistically significant differences indicate that the sensitivities of the responses to cold and AITC to the SMase treatments were rather similar. 
a

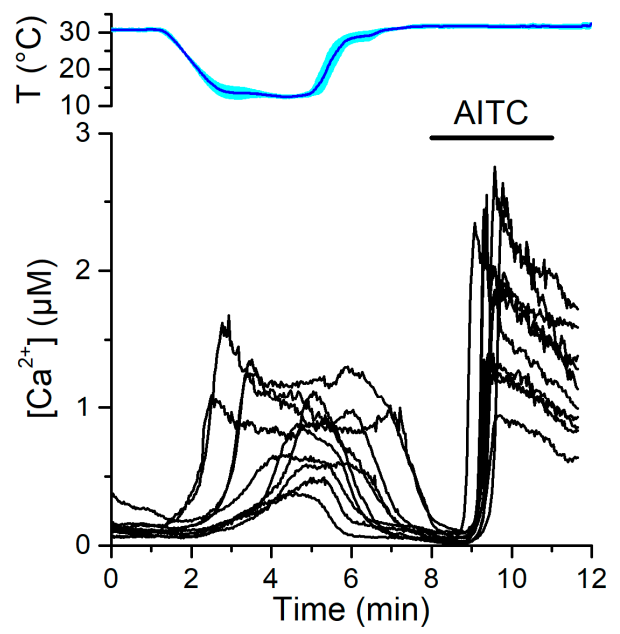

C
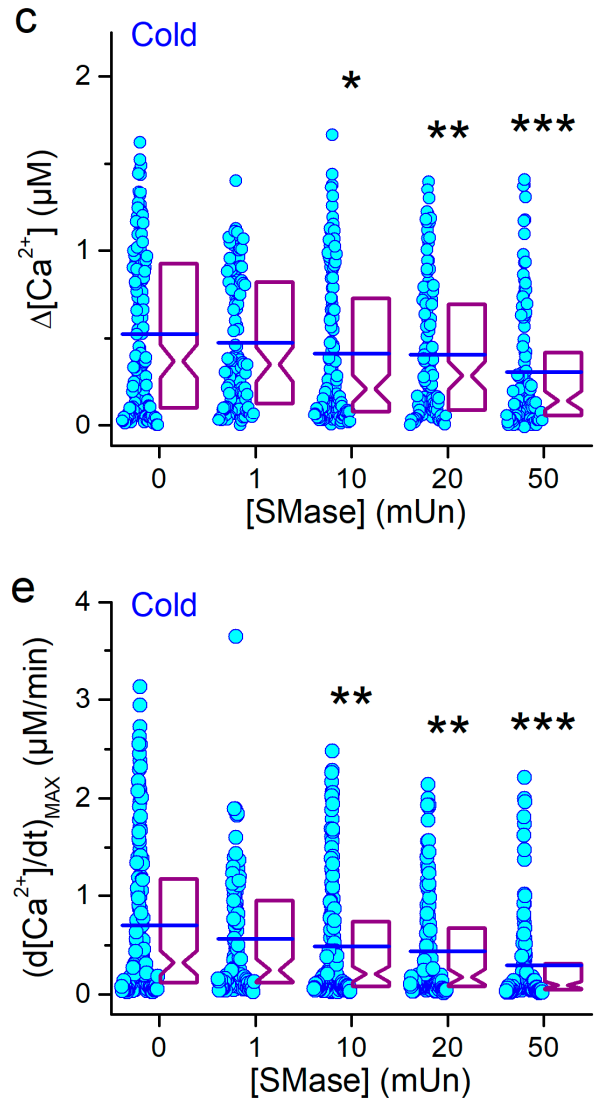

b
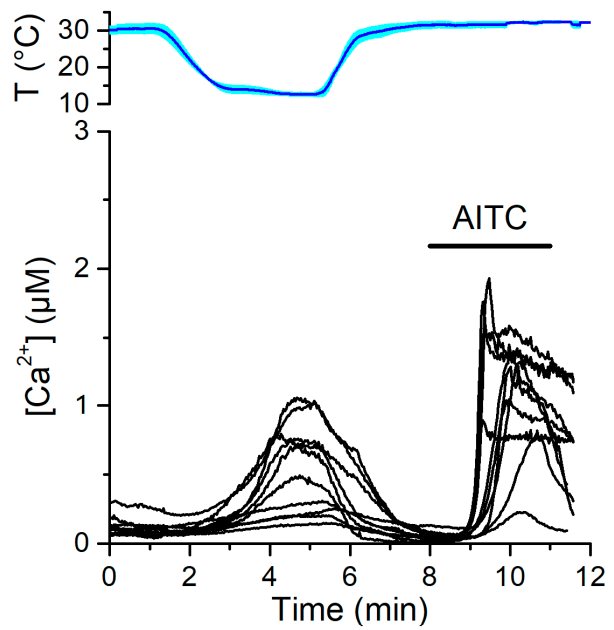

d

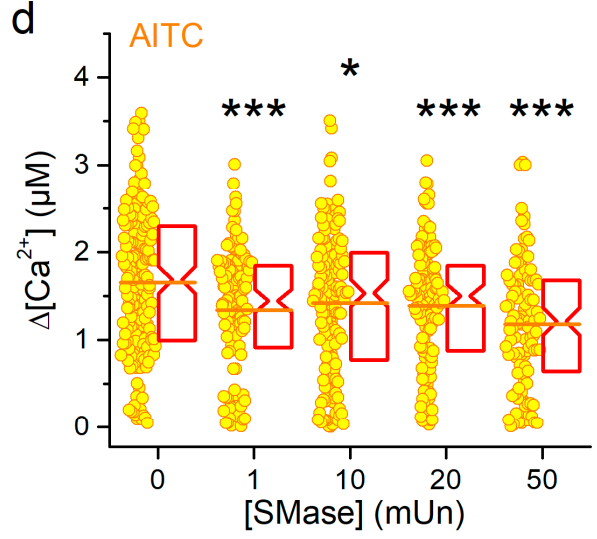

f

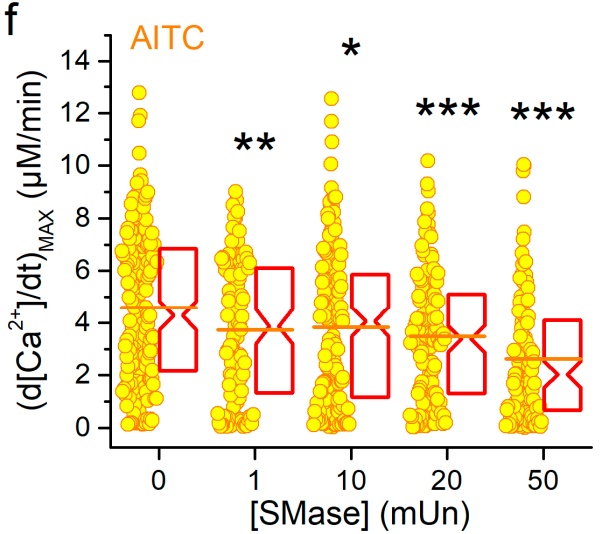

Figure 2. Effects of SMase pretreatment on mTRPA1 responses to cold. (a and b) Representative traces of $\left[\mathrm{Ca}^{2+}\right]$ change induced by cold in the control condition (a) and after pretreatment with 50 mUN SMase (b). Application of AITC $(100 \mu \mathrm{M})$ was used as control for mTRPA1 activation. (c and d) Amplitudes of $\left[\mathrm{Ca}^{2+}\right]$ responses evoked by cold (c) and AITC $(d)$ in control condition $(n=183)$ or after pretreatment with $1(n=126), 10(n=164), 20(n=135)$ or $50 \mathrm{mUN}(n=111)$ of SMase. (e and f) Maximal amplitudes of the first time derivative of the intracellular $\mathrm{Ca}^{2+}$ signal elicited by cold (e) and AITC (f) in control condition or after treatment with 1, 10, 20 or $50 \mathrm{mUN}$ of MCD (the $n$ numbers are the same as in panels $\mathrm{c}$ and $\mathrm{d}$ ). The symbols ${ }^{*}{ }^{* *}$ and ${ }^{* *}$ indicate $p<0.05, p<0.01$ and $p<0.001$, respectively; Kolmogorov-Smirnov test. 


\subsection{Cholesterol Depletion Reduces mTRPA1 Response to Bacterial Lipopolysaccharides}

Extracellular application of Escherichia coli (E. coli) LPS $(20 \mu \mathrm{g} / \mathrm{mL})$ triggered intracellular Ca ${ }^{2+}$ responses (Figure 3a,c), as previously reported [32,33]. The amplitudes of LPS-induced responses did not follow a normal distribution, but were distributed in two groups, one with small values and the other with amplitudes larger than $0.75 \mu \mathrm{M}$ (Figure 3c). The maximal rising rate showed a similar trend (Figure 3e). Pretreatment with MCD 1 or $5 \mathrm{mM}$ did not result in statistically significant changes in these magnitudes, but a modest reduction was found in cells pretreated with $10 \mathrm{mM} \mathrm{MCD}$ (Figure 3b,c,e). The responses to AITC were confirmed to be reduced by 1,5 and $10 \mathrm{MCD}$ (Figure $3 \mathrm{~b}, \mathrm{~d}, \mathrm{f}$ ).
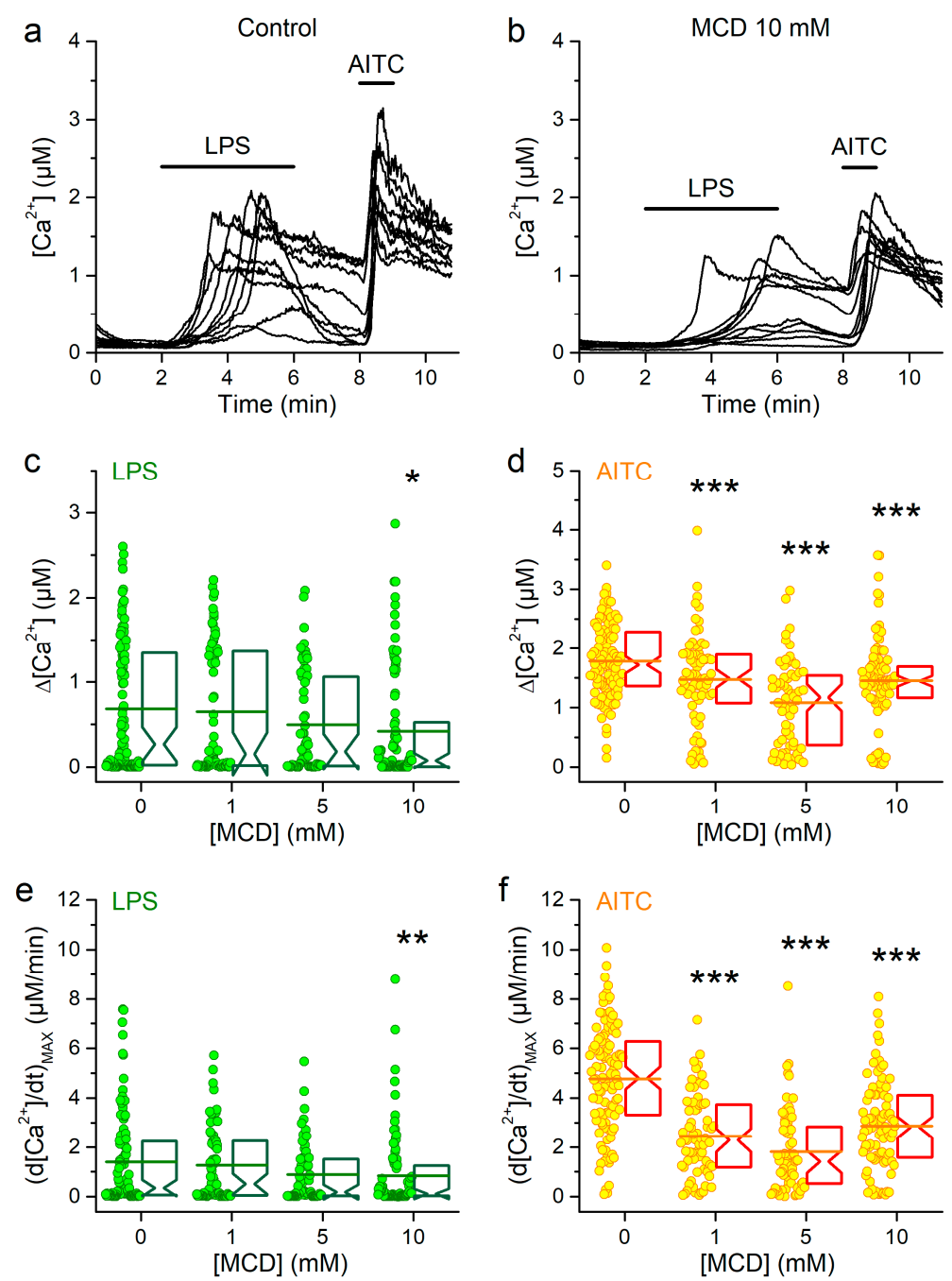

Figure 3. Effects of cholesterol depletion using MCD on mTRPA1 responses to LPS. (a and $\mathbf{b}$ ) Representative $\left[\mathrm{Ca}^{2+}\right]$ traces showing the effects of E. coli LPS $(20 \mu \mathrm{g} / \mathrm{mL})$ in control condition (a) and after pretreatment with $10 \mathrm{mM} \mathrm{MCD} \mathrm{(b).} \mathrm{Application} \mathrm{of} \mathrm{AITC}(100 \mu \mathrm{M})$ was used as control for mTRPA1 activation. (c and d) Amplitudes of $\left[\mathrm{Ca}^{2+}\right]$ responses to LPS (c) and AITC (d) in control $(n=102)$ or after pretreatment with $1(n=72), 5(n=64)$ or $10 \mathrm{mM}(n=90)$ of MCD. Maximal amplitude of the first time derivative of the intracellular $\mathrm{Ca}^{2+}$ signal elicited by LPS (e) and AITC (f) in control condition or after treatment with 1,5 or $10 \mathrm{mM}$ of MCD (the $n$ numbers are the same as in panels $\mathrm{c}$ and d). The symbols $* * *$ and ${ }^{* * *}$ indicate $p<0.05, p<0.01$ and $p<0.001$, respectively; Kolmogorov-Smirnov test.

Next, we determined the effects of pretreatments with SMase (1-50 mUN) on the responses to LPS. We found statistically significant decrease in the amplitude and the maximal rising rate of the responses to LPS only for the highest concentration (Figure $4 \mathrm{a}-\mathrm{c}, \mathrm{e})$. This contrasts with the significant 
effects on the responses to AITC, which were found from $10 \mathrm{mUN}$ for the amplitudes (Figure 4d) and from $1 \mathrm{mUN}$ for the maximal rising rate (Figure 4f). Taken together our results show that the MCD and SMase treatments had a smaller influence on the action of LPS than on those of cold and AITC.
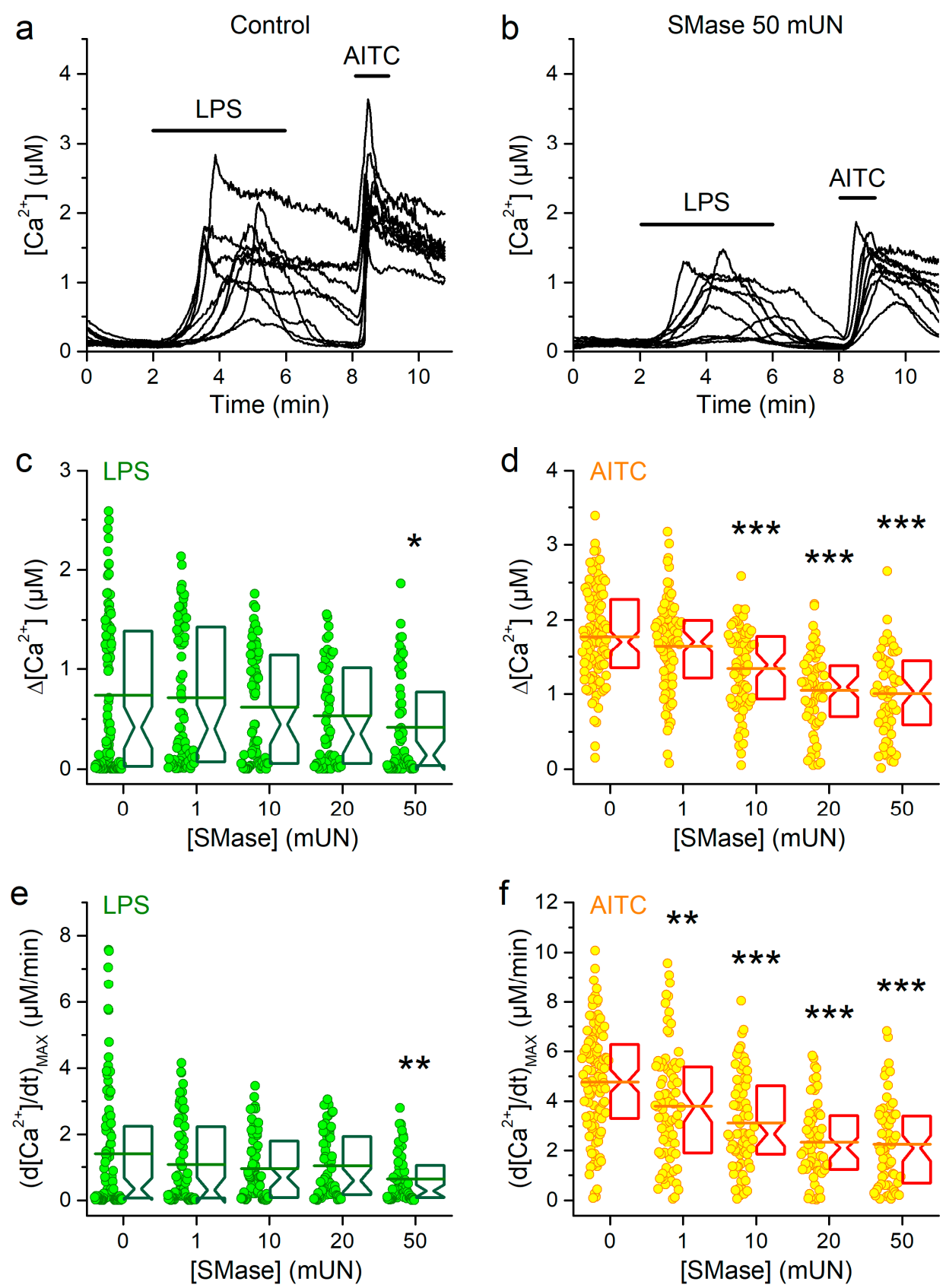

Figure 4. Effects of SMase pretreatment on mTRPA1 responses to LPS. (a and $\mathbf{b})$ Representative $\left[\mathrm{Ca}^{2+}\right.$ ] traces showing the effects of E. coli LPS $(20 \mu \mathrm{g} / \mathrm{mL})$ in control condition (a) and after pretreatment with 50 mUN SMase (b). Application of AITC $(100 \mu \mathrm{M})$ was used as control for mTRPA1 activation. (c and d) Average amplitude of $\left[\mathrm{Ca}^{2+}\right]$ responses to LPS (c) and AITC (d) in control condition $(n=108)$ or after pretreatment with $1(n=83), 10(n=75), 20(n=60)$ or $50 \mathrm{mUN}(n=64)$ of SMase. Maximal amplitude of the first time derivative of the intracellular $\mathrm{Ca}^{2+}$ signal elicited by LPS (e) and AITC (f) in control condition or after treatment with 1, 10, 20 or $50 \mathrm{mUN}$ of SMase (the $n$ numbers are the same as in panels $\mathrm{c}$ and $\mathrm{d}$ ). The symbols ${ }^{*}{ }^{* *}$ and ${ }^{* * *}$ indicate $p<0.05, p<0.01$ and $p<0.001$, respectively; Kolmogorov-Smirnov test. 


\subsection{Cholesterol Depletion Reduces Sensitivity but Not the Maximal Response of mTRPA1 to AITC}

The weaker effects of lipid raft disruption on the responses to LPS cannot be explained by a decrease in channel expression as a main effect of cholesterol depletion because this would affect the action of all stimuli in similar extents. In turn, this raised the question of whether such an effect actually occurs in CHO-K1 cells, as we have previously documented in HEK293T cells [31]. To test this, we performed another series of experiments, to compare the concentration-dependence curves for AITC determined in the control and after pretreatment with $10 \mathrm{mM}$ MCD in mTRPA1 CHO-K1 cells, and to see whether the treatment reduces the maximal response to this compound. We tested AITC at concentrations up to $200 \mu \mathrm{M}$ because at higher values we have seen an inhibitory effect [41]. In control cells AITC triggered $\mathrm{Ca}^{2+}$ responses in a concentration-dependent manner, with an $\mathrm{EC}_{50}$ of $4.6 \pm 1.1$ $\mu \mathrm{M}$ (Figure 5a-left,b). In cells pretreated with MCD the $\mathrm{EC}_{50}$ was 15 -fold higher (Figure 5a-right,b), thus qualitatively similar to the effect reported in our previous study in HEK293 cells [31]. However, the estimated maximal responses to AITC were not different between control and MCD-treated cells $(1.32 \pm 0.09 \mu \mathrm{M}$ and $1.4 \pm 0.3 \mu \mathrm{M}$, respectively). This indicates that the expression of mTRPA1 is not altered by the reduction of cholesterol in the CHO-K1 stable expression system, and that the most salient effect is that on the channel gating.
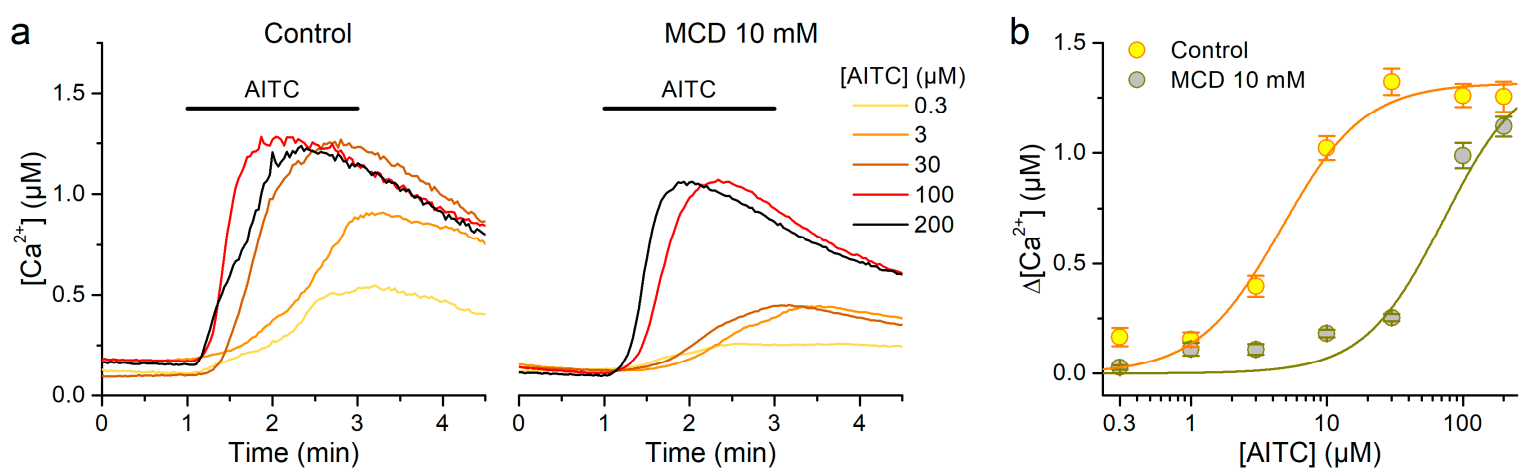

Figure 5. Effects of cholesterol depletion using MCD on mTRPA1 activation by AITC in stably transfected CHO-K1 cells. (a) Mean traces of $\mathrm{Ca}^{2+}$ responses to different concentrations of AITC in control (left panel) or after treatment with $10 \mathrm{mM} \mathrm{MCD} \mathrm{(right} \mathrm{panel;} n=63-178$ ). (b) Dose-response curves of the amplitude of the $\mathrm{Ca}^{2+}$ responses to AITC averaged over different cells. The lines represent fits with Hill functions with parameters $\mathrm{EC}_{50}=4.6 \pm 1.1 \mu \mathrm{M}$ and $70 \pm 20 \mu \mathrm{M}, \Delta\left[\mathrm{Ca}^{2+}\right]_{\mathrm{MAX}}=1.32 \pm 0.09$ $\mu \mathrm{M}$ and $1.4 \pm 0.3 \mu \mathrm{M}$ and $\mathrm{H}=1.4 \pm 0.3$ and $1.5 \pm 0.5$, for control and MCD $10 \mathrm{mM}$, respectively.

\section{Discussion}

The survival of living organisms vastly relies on a constant monitoring of the external and inner chemical environments, allowing for adequate protective reactions against harmful stimuli. This is particularly important for the detection of noxious chemicals, changes in temperature and osmolarity and mechanical stimuli. TRPA1 plays an important role in the detection of harmful thermal, mechanical and chemical stimuli $[28,29]$. For instance, TRPA1 is activated by electrophilic compounds such as AITC and cinnamaldehyde, through a mechanism that involves covalent modification of cysteine residues [34,35]. This channel is also activated by a large group of non-electrophilic chemicals that may induce mechanical perturbations upon insertion in the plasma membrane [28]. Recently, TRPA1 activation was associated with channel's ability to sense changes in the order of the surrounding bilayer [33]. It has been proposed that bacterial LPS activated TRPA1 [32,33,42] in non-canonical way, by inducing changes in the mechanical properties of the membrane, which may be detected by the channel [33]. Multiple TRPA1 agonists such as trinitrophenol and chlorpromazine [43], primary alcohols [44], parabens [45], phenolic compounds [46], farnesyl thiosalicylic acid and its analogs [47], 6-gingerol analogs [48,49], menthol [50] and camphor [51] are also able to partition into the plasma 
membrane, thereby inducing alterations in the channel local environment, such as changes in the curvature, tension and/or thickness.

Regardless of the growing indications that membrane properties and composition are crucial for TRPA1 activation by multiple chemicals, the mechanism of channel activation remains elusive. TRPA1 function and localization pattern has been linked to cholesterol levels in the membrane. This channel was shown to be expressed in specific membrane domains characterized by high concentrations of specific lipids such as cholesterol, gangliosides and sphingolipids [11,31,52]. Modification of the composition of lipid rafts by bilayer destabilizers, such as MCD and SMase, strongly reduces mTRPA1 chemosensitivity to electrophilic (AITC) and non-electrophilic (thymol) agonists [31]. However, it remained unknown whether modifications of cholesterol and sphingolipids levels also affect the response of mTRPA1 to stimuli of distinct nature. In this study we present data showing that this is indeed the case, although to different extents, for the activation of by cold and LPS.

The fact that alterations of the membrane composition affect mTRPA1 responses to very distinct stimuli (chemical: AITC and thymol [31] and physical: cold and LPS, present results) further supports the idea that artificial expression systems may be of limited reach in the understanding of channel structure and function [31]. In a similar line, variations in the lipid environment of TRPA1 across expression systems or in the presence of lipid-channel interaction sites might contribute to the distinct functional properties of isoforms reported in the literature. In this sense, as done previously in structure-function analyses (see for review $[13,28,29,53]$ ), future studies may test the role of lipid-channel interactions exploiting the fact that, depending on the species, TRPA 1 channels can be activated by heat $[13,16,54-58]$, by cold $[14,17,18,57]$ or insensitive to cold $[13,59]$. Of particular interest is the new technical possibility of studying TRPA1 in artificial membranes $[16,17,25]$, which in principle may allow determining the influence of individual lipid components on the membrane expression pattern and the functional properties of the channel.

Regarding the mechanism underlying the reduction of mTRPA1 responses by cholesterol depletion, it was previously shown that treatment with MCD induced a dual action in HEK293T cells: a decrease in the sensitivity for stimulation with AITC (increased $\mathrm{EC}_{50}$ ) and a reduction in the number of channels expressed at the plasma membrane. A major finding of the present study is that the latter effect does not seem to occur in the CHO-K1 expression system, as we found that the responses to AITC at high concentrations we nearly identical. The reason for this difference remains unclear, but could be related to the type of heterologous expression, transient vs. stable transfection, as in the former the levels of mTRPA1 expression are higher and could therefore be more liable to a decrease by the change in membrane composition.

The present experiments did, however, recapitulate the decrease in sensitivity to AITC, i.e., a 15 -fold increase in the $\mathrm{EC}_{50}$, which is actually larger than the 5-fold increase found previously in HEK293T cells [31]. Thus, we conclude, first, that the most consistent effect of cholesterol depletion on mTRPA1 was the reduction of the channel's sensitivity to stimulation, and second, that the reduction in the responses to cold and LPS we reported here cannot be explained by a decrease in the channel expression at the plasma membrane.

Interestingly, cholesterol depletion was reported to produce an opposite effect on TRPM8, enhancing the responses of this channel to cold [9]. The mechanisms underlying the regulation of TRPM8 by cholesterol remain unknown, but were discussed in terms of possible influence of changes in membrane fluidity, direct interactions with raft-specific lipids and channel regulation by other membrane proteins confined to cholesterol-enriched membrane domains [9]. It could be argued that the fluidizing effect that MCD and SMase have on the membrane may counteract the rigidifying effect of cold. This might reduce the ability of cold to stimulate mTRPA1, as the increase in membrane order was recently related to the activation of this channel $[23,33]$.

As for the stimulation of mTRPA1 by LPS, the disruption of lipid rafts may impair the insertion of LPS in the membrane. Indeed, it has been shown that cholesterol plays a key role in LPS-membrane interactions, and that LPS has high binding affinity to phosphatidylcholine-, sphingomyelin- and 
cholesterol-containing artificial membranes that mimic lipid rafts [60,61]. Another salient result of our present study is that the stimulation of mTRPA1 by LPS was more resistant to the treatments with MCD and SMase, as the effects were observed at higher concentration than for cold and AITC. This finding further supports the idea that cholesterol depletion does not significantly affect mTRPA1 expression in $\mathrm{CHO}-\mathrm{K} 1$ cells, but reduces the sensitivity of the channels to the different stimuli in distinct manners.

Interestingly, the role of lipid rafts in the interactions that mediate the invasion of host cells by pathogenic microorganisms have been extensively studied over the last few years [62], and it is known that the canonical LPS detection machinery in immune cells is supported by raft clustering of signaling proteins such as Toll-like receptor 4 (TLR4) [63,64], GPI-anchored proteins [65], for example CD14 [66] and other pro-inflammatory protein complexes [63]. The similarities of the membrane contexts required by both the LPS-induced TRPA1 activation and the well-established TLR4-mediated signaling constitutes further support to the idea that TRPA1 indeed functions as a detector of endotoxins, triggering fast defense mechanisms against gram-negative bacterial infections mediated by sensory neurons [32].

Taken together, our findings support the hypotheses that mTRPA1 activation by multiple stimuli, including electrophilic and non-electrophilic agonists, as well as cold and bacterial endotoxins, depends on the local lipid environment. The role of sensory TRP channels in the induction of pain and neurogenic inflammation in the context of bacterial infections $[23,27,32,67]$ suggest them as possible direct therapeutic targets. However, our data, together with previous findings indicating that cholesterol-lowering drugs improve neuropathic pain [68], suggest that lipid-TRPA1 channel interactions could be also used in the treatment of infections.

\section{Materials and Methods}

\subsection{Cell Culture}

Chinese hamster ovary (CHO-K1) cells from the American Type Culture Collection were grown in DMEM containing 10\% fetal bovine serum, 2\% glutamax (Gibco/Invitrogen), 1\% non-essential amino acids (Invitrogen) and $200 \mu \mathrm{g} / \mathrm{mL}$ penicillin/streptomycin at $37^{\circ} \mathrm{C}$ in a humidity-controlled incubator with $5 \% \mathrm{CO}_{2}$. As mTRPA1 expression system we used CHO-K1 cells stably transfected with MTRPA1 [18].

\subsection{Disruption of Lipid Rafts with MCD or SMase}

Cells were washed with serum-free culture medium and incubated with different concentrations (1-10 mM) of methyl- $\beta$-cyclodextrine (MCD; Sigma-Aldrich) or sphingomyelinase (SMase; $1-50 \mathrm{mUN}$ ) from Bacillus cereus (Sigma-Aldrich) for $1 \mathrm{~h}$ at $37^{\circ} \mathrm{C}$ in a humidity-controlled incubator. According to previous studies [69-71], none of these treatments are expected to induce significant cytotoxic effects, which we confirmed by inspecting the cell morphology.

After these treatments the cells were washed and used for intracellular $\mathrm{Ca}^{2+}$ imaging experiments within $5 \mathrm{~min}$. None of our experimental solutions contained serum, which would otherwise support de-novo cholesterol synthesis. Although the rate of cholesterol redistribution in native membrane bilayers remains unknown, we are confident that we do induce reduction of cholesterol and sphingomyelin levels, as many other studies reports [72-76].

\subsection{Ratiometric Intracellular $\mathrm{Ca}^{2+}$ Imaging}

For intracellular $\mathrm{Ca}^{2+}$ imaging experiments cells were incubated with $2 \mu \mathrm{M}$ Fura-2 AM (Biotium, Hayward, CA, USA) for $40 \mathrm{~min}$ at $37^{\circ} \mathrm{C}$ in a humidity-controlled incubator. Fluorescence was measured with alternating excitation at 340 and $380 \mathrm{~nm}$ using a monochromator-based imaging system consisting of an MT-10 illumination system (Tokyo, Japan) and Cell ${ }^{\mathrm{M}}$ software from Olympus. All experiments were performed using the standard Krebs solution (see above) at $25^{\circ} \mathrm{C}$. Fluorescence intensities were corrected for background signal and presented as the ratio F340/F380 from which intracellular $\mathrm{Ca}^{2+}$ 
concentration was calculated as described previously [77]. Data were analyzed and presented as mean \pm s.e.m. using Origin 9.0 (OriginLab Corporation).

\subsection{Data and Statistical Analysis}

If not stated otherwise, the non-parametric Kolmogorov-Smirnov test was used to assess statistical significance. Most results are shown using notched box plots in which the data is presented as individual values (scatter data symbols), along with the median (position of the notch center), the mean (horizontal line), the 25 and 75 percentiles (vertical box limits) and the $95 \%$ confidence interval of the median (notch). Asterisks represent the significance $\left({ }^{*} p<0.05 ;{ }^{* *} p<0.01 ; * * * p<0.001\right)$ and $n$ denotes the sample size. The concentration-dependence of AITC effects is shown as mean \pm s.e.m.

The concentration-dependence curves for the stimulatory effect of AITC on mTRPA1 were fit by a Hill function of the form:

$$
\Delta\left[\mathrm{Ca}^{2+}\right]=\frac{\operatorname{Max} \times[\text { AITC }]^{H}}{[\text { AITC }]^{H}+E C_{50}^{H}}
$$

where Max is the maximal increase in intracellular $\mathrm{Ca}^{2+}$ levels obtained at high concentrations of AITC ([AITC]); $E C_{50}$ is the half effective concentration and $H$ is the Hill coefficient.

Author Contributions: J.B.S. and K.T. conceived and designed all experiments. J.B.S. performed experiments. J.B.S. and K.T. analyzed the data. J.B.S. and K.T. wrote, reviewed and edited the manuscript. K.T. supervised and funded the project. All authors have read and agreed to the published version of the manuscript.

Funding: This work was supported by grants of the Research Council of the KU Leuven (GOA/14/011 and C14/18/086) and the Fund for Scientific Research Flanders (FWO: G070212N, G0C7715N and G0D0417N).

Acknowledgments: We thank M. Benoit for excellent technical assistance and the members of the LICR laboratory for helpful discussions. The CHO-mTRPA1 cell line was kindly provided by Ardem Patapoutian (The Scripps Research Institute, USA).

Conflicts of Interest: The authors declare no conflict of interest.

\section{Abbreviations}

$\begin{array}{ll}\text { AITC } & \text { Allyl isothiocyanate } \\ \text { CD14 } & \text { Cluster of differentiation } 14 \\ \text { CRAC } & \text { Cholesterol recognition amino acid consensus motif } \\ \text { GPI-anchored proteins } & \text { Glycosylphosphatidylinositol anchored proteins } \\ \text { LPS } & \text { Bacterial lipopolysaccharides } \\ \text { MCD } & \text { Methyl } \beta \text {-cyclodextrin } \\ \text { SM } & \text { Sphingomyelin } \\ \text { SMase } & \text { Sphingomyelinase } \\ \text { TLR4 } & \text { Toll-like receptor 4 } \\ \text { TM } & \text { Transmembrane domain } \\ \text { TNT } & \text { Trinitrophenol } \\ \text { TRPA1 } & \text { Transient receptor potential ankyrin } 1 \text { cation channel } \\ \text { TRPM8 } & \text { Transient receptor potential melastatin } 8 \text { cation channel } \\ \text { TRPV1 } & \text { Transient receptor potential vanilloid } 1 \text { cation channel }\end{array}$

\section{References}

1. Van Meer, G.; Voelker, D.R.; Feigenson, G.W. Membrane lipids: Where they are and how they behave. Nat. Rev. Mol. Cell Boil. 2008, 9, 112-124. [CrossRef] [PubMed]

2. Goni, F.M. The basic structure and dynamics of cell membranes: An update of the Singer-Nicolson model. Biochim. Biophys. Acta (BBA) Biomembr. 2014, 1838, 1467-1476. [CrossRef] [PubMed]

3. Simons, K.; Vaz, W. Model Systems, Lipid Rafts, and Cell Membranes. Annu. Rev. Biophys. Biomol. Struct. 2004, 33, 269-295. [CrossRef] [PubMed] 
4. Bloom, M.; Evans, E.; Mouritsen, O.G. Physical properties of the fluid lipid-bilayer component of cell membranes: A perspective. Q. Rev. Biophys. 1991, 24, 293-397. [CrossRef] [PubMed]

5. Barenholz, Y. Cholesterol and other membrane active sterols: From membrane evolution to "rafts". Prog. Lipid Res. 2002, 41, 1-5. [CrossRef]

6. Simons, K.; Sampaio, J. Membrane Organization and Lipid Rafts. Cold Spring Harb. Perspect. Boil. 2011, 3, a004697. [CrossRef] [PubMed]

7. Liu, B.; Hui, K.; Qin, F. Thermodynamics of Heat Activation of Single Capsaicin Ion Channels VR1. Biophys. J. 2003, 85, 2988-3006. [CrossRef]

8. Liu, M.; Huang, W.; Wu, N.; Priestley, J.V. TRPV1, but not P2X3, requires cholesterol for its function and membrane expression in rat nociceptors. Eur. J. Neurosci. 2006, 24, 1-6. [CrossRef] [PubMed]

9. Morenilla-Palao, C.; Pertusa, M.; Meseguer, V.; Cabedo, H.; Viana, F. Lipid Raft Segregation Modulates TRPM8 Channel Activity. J. Boil. Chem. 2009, 284, 9215-9224. [CrossRef]

10. Naylor, J.; Li, J.; Milligan, C.J.; Zeng, F.; Sukumar, P.; Hou, B.; Sedo, A.; Yuldasheva, N.; Majeed, Y.; Beri, D.; et al. Pregnenolone sulphate- and cholesterol-regulated TRPM3 channels coupled to vascular smooth muscle secretion and contraction. Circ. Res. 2010, 106, 1507-1515. [CrossRef]

11. Sághy, É.; Szőke, É.; Payrits, M.; Helyes, Z.; Borzsei, R.; Erostyák, J.; Jánosi, T.Z.; Jánositáló, G., Jr.; Szolcsányi, J. Evidence for the role of lipid rafts and sphingomyelin in $\mathrm{Ca}^{2+}$-gating of Transient Receptor Potential channels in trigeminal sensory neurons and peripheral nerve terminals. Pharm. Res. 2015, 100, 101-116. [CrossRef]

12. Szőke, É.; Borzsei, R.; Tóth, D.M.; Lengl, O.; Helyes, Z.; Sándor, Z.; Szolcsányi, J. Effect of lipid raft disruption on TRPV1 receptor activation of trigeminal sensory neurons and transfected cell line. Eur. J. Pharm. 2010, 628, 67-74. [CrossRef]

13. Chen, J.; Kang, D.; Xu, J.; Lake, M.; Hogan, J.O.; Sun, C.; Walter, K.; Yao, B.; Kim, N. Species differences and molecular determinant of TRPA1 cold sensitivity. Nat. Commun. 2013, 4, 2501. [CrossRef] [PubMed]

14. Karashima, Y.; Talavera, K.; Everaerts, W.; Janssens, A.; Kwan, K.; Vennekens, R.; Nilius, B.; Voets, T. TRPA1 acts as a cold sensor in vitro and in vivo. Proc. Natl. Acad. Sci. USA 2009, 106, 1273-1278. [CrossRef]

15. Kwan, K.; Allchorne, A.J.; Vollrath, M.A.; Christensen, A.P.; Zhang, D.-S.; Woolf, C.J.; Corey, D.P. TRPA1 Contributes to Cold, Mechanical, and Chemical Nociception but Is Not Essential for Hair-Cell Transduction. Neuron 2006, 50, 277-289. [CrossRef] [PubMed]

16. Moparthi, L.; Kichko, T.I.; Eberhardt, M.; Högestätt, E.D.; Kjellbom, P.; Johanson, U.; Reeh, P.W.; Leffler, A.; Filipovic, M.R.; Zygmunt, P. Human TRPA1 is a heat sensor displaying intrinsic U-shaped thermosensitivity. Sci. Rep. 2016, 6, 28763. [CrossRef]

17. Moparthi, L.; Survery, S.; Kreir, M.; Simonsen, C.; Kjellbom, P.; Högestätt, E.; Johanson, U.; Zygmunt, P. Human TRPA1 is intrinsically cold- and chemosensitive with and without its N-terminal ankyrin repeat domain. Proc. Natl. Acad. Sci. USA 2014, 111, 16901-16906. [CrossRef]

18. Story, G.M.; Peier, A.M.; Reeve, A.J.; Eid, S.R.; Mosbacher, J.; Hricik, T.R.; Earley, T.J.; Hergarden, A.C.; Andersson, D.A.; Hwang, S.W.; et al. ANKTM1, a TRP-like Channel Expressed in Nociceptive Neurons, Is Activated by Cold Temperatures. Cell 2003, 112, 819-829. [CrossRef]

19. Survery, S.; Moparthi, L.; Kjellbom, P.; Högestätt, E.D.; Zygmunt, P.; Johanson, U. The N-terminal Ankyrin Repeat Domain Is Not Required for Electrophile and Heat Activation of the Purified Mosquito TRPA1 Receptor*. J. Boil. Chem. 2016, 291, 26899-26912. [CrossRef]

20. Vandewauw, I.; De Clercq, K.; Mulier, M.; Held, K.; Pinto, S.; Van Ranst, N.; Segal, A.; Voet, T.; Vennekens, R.; Zimmermann, K.; et al. A TRP channel trio mediates acute noxious heat sensing. Nature 2018, 555, 662-666. [CrossRef]

21. Viswanath, V.; Story, G.M.; Peier, A.M.; Petrus, M.J.; Lee, V.M.; Hwang, S.W.; Patapoutian, A.; Jegla, T. Opposite thermosensor in fruitfly and mouse. Nature 2003, 423, 822-823. [CrossRef] [PubMed]

22. Fajardo, O.; Meseguer, V.; Belmonte, C.; Viana, F. TRPA1 Channels Mediate Cold Temperature Sensing in Mammalian Vagal Sensory Neurons: Pharmacological and Genetic Evidence. J. Neurosci. 2008, 28, 7863-7875. [CrossRef] [PubMed]

23. Startek, J.; Boonen, B.; Talavera, K.; Meseguer, V. TRP Channels as Sensors of Chemically-Induced Changes in Cell Membrane Mechanical Properties. Int. J. Mol. Sci. 2019, 20, 371. [CrossRef] [PubMed]

24. Kindt, K.; Viswanath, V.; MacPherson, L.; Quast, K.; Hu, H.; Patapoutian, A.; Schafer, W.R. Caenorhabditis elegans TRPA-1 functions in mechanosensation. Nat. Neurosci. 2007, 10, 568-577. [CrossRef] [PubMed] 
25. Moparthi, L.; Zygmunt, P.M. Human TRPA1 is an inherently mechanosensitive bilayer-gated ion channel. bioRxiv 2020. [CrossRef]

26. Zhang, X.-F.; Chen, J.; Faltynek, C.R.; Moreland, R.B.; Neelands, T.R. Transient receptor potential A1 mediates an osmotically activated ion channel. Eur. J. Neurosci. 2008, 27, 605-611. [CrossRef]

27. Boonen, B.; Alpizar, Y.A.; Meseguer, V.; Talavera, K. TRP Channels as Sensors of Bacterial Endotoxins. Toxins 2018, 10, 326. [CrossRef]

28. Talavera, K.; Startek, J.B.; Alvarez-Collazo, J.; Boonen, B.; Alpizar, Y.A.; Sanchez, A.; Naert, R.; Nilius, B. Mammalian Transient Receptor Potential TRPA1 Channels: From Structure to Disease. Physiol. Rev. 2020, 100, 725-803. [CrossRef]

29. Zygmunt, P.; Högestätt, E. TRPA1. Pharmacol. Ther. Cough 2014, 222, 583-630. [CrossRef]

30. Startek, J.; Voets, T.; Talavera, K. To flourish or perish: Evolutionary TRiPs into the sensory biology of plant-herbivore interactions. Pflügers Arch. 2018, 471, 213-236. [CrossRef]

31. Startek, J.; Boonen, B.; Requena, A.L.; Talavera, A.; Alpizar, Y.A.; Ghosh, D.; Van Ranst, N.; Nilius, B.; Voets, T.; Talavera, K. Mouse TRPA1 function and membrane localization are modulated by direct interactions with cholesterol. eLife 2019, 8, 8. [CrossRef] [PubMed]

32. Meseguer, V.; Alpizar, Y.A.; Luis, E.; Tajada, S.; Denlinger, B.; Fajardo, O.; Manenschijn, J.-A.; Fernandez-Peña, C.; Talavera, A.; Kichko, T.; et al. TRPA1 channels mediate acute neurogenic inflammation and pain produced by bacterial endotoxins. Nat. Commun. 2014, 5, 3125. [CrossRef] [PubMed]

33. Startek, J.; Talavera, K.; Voets, T.; Alpizar, Y.A. Differential interactions of bacterial lipopolysaccharides with lipid membranes: Implications for TRPA1-mediated chemosensation. Sci. Rep. 2018, 8, 12010. [CrossRef] [PubMed]

34. Hinman, A.; Chuang, H.-H.; Bautista, D.M.; Julius, D. TRP channel activation by reversible covalent modification. Proc. Natl. Acad. Sci. 2006, 103, 19564-19568. [CrossRef] [PubMed]

35. MacPherson, L.; Dubin, A.E.; Evans, M.J; Marr, F.; Schultz, P.G.; Cravatt, B.F.; Patapoutian, A. Noxious compounds activate TRPA1 ion channels through covalent modification of cysteines. Nature 2007, 445, 541-545. [CrossRef] [PubMed]

36. Alpizar, Y.A.; Sánchez, A.; Radwan, A.; Radwan, I.; Voets, T.; Talavera, K. Lack of correlation between the amplitudes of TRP channel-mediated responses to weak and strong stimuli in intracellular $\mathrm{Ca}^{2+}$ imaging experiments. Cell Calcium 2013, 54, 362-374. [CrossRef]

37. Hanada, K.; Nishijima, M.; Kiso, M.; Hasegawa, A.; Fujita, S.; Ogawa, T.; Akamatsu, Y. Sphingolipids are essential for the growth of Chinese hamster ovary cells. Restoration of the growth of a mutant defective in sphingoid base biosynthesis by exogenous sphingolipids. J. Boil. Chem. 1992, 267, 23527-23533.

38. López-Montero, I.; Monroy, F.; Vélez, M.; Devaux, P.F. Ceramide: From lateral segregation to mechanical stress. Biochim. Biophys. Acta (BBA) Biomembr. 2010, 1798, 1348-1356. [CrossRef]

39. Latorre, E.; Aragones, M.D.; Fernandez, I.; Catalan, R.E. Platelet-activating factor modulates brain sphingomyelin metabolism. JBIC J. Boil. Inorg. Chem. 1999, 262, 308-314. [CrossRef]

40. Yu, C.; Alterman, M.; Dobrowsky, R.T. Ceramide displaces cholesterol from lipid rafts and decreases the association of the cholesterol binding protein caveolin-1. J. Lipid Res. 2005, 46, 1678-1691. [CrossRef]

41. Everaerts, W.; Gees, M.; Alpizar, Y.A.; Farré, R.; Leten, C.; Apetrei, A.; Dewachter, I.; Van Leuven, F.; Vennekens, R.; De Ridder, D.; et al. The Capsaicin Receptor TRPV1 Is a Crucial Mediator of the Noxious Effects of Mustard Oil. Curr. Boil. 2011, 21, 316-321. [CrossRef] [PubMed]

42. Soldano, A.; Alpizar, Y.A.; Boonen, B.; Franco, L.; Requena, A.L.; Liu, G.; Mora, N.; Yaksi, E.; Voets, T.; Vennekens, R.; et al. Gustatory-mediated avoidance of bacterial lipopolysaccharides via TRPA1 activation in Drosophila. eLife 2016, 5, 507. [CrossRef] [PubMed]

43. Hill, K.; Schaefer, M. TRPA1 Is Differentially Modulated by the Amphipathic Molecules Trinitrophenol and Chlorpromazine. J. Boil. Chem. 2007, 282, 7145-7153. [CrossRef]

44. Komatsu, T.; Uchida, K.; Fujita, F.; Zhou, Y.; Tominaga, M. Primary alcohols activate human TRPA1 channel in a carbon chain length-dependent manner. Pflügers Arch. 2012, 463, 549-559. [CrossRef] [PubMed]

45. Fujita, F.; Moriyama, T.; Higashi, T.; Shima, A.; Tominaga, M. Methyl p-hydroxybenzoate causes pain sensation through activation of TRPA1 channels. Br. J. Pharm. 2007, 151, 153-160. [CrossRef] [PubMed]

46. Lee, S.P.; Buber, M.T.; Yang, Q.; Cerne, R.; Cortés, R.Y.; Sprous, D.G.; Bryant, R.W. Thymol and related alkyl phenols activate the hTRPA1 channel. Br. J. Pharm. 2008, 153, 1739-1749. [CrossRef] [PubMed] 
47. Maher, M.; Ao, H.; Banke, T.; Nasser, N.; Wu, N.-T.; Breitenbucher, J.G.; Chaplan, S.R.; Wickenden, A.D. Activation of TRPA1 by Farnesyl Thiosalicylic Acid. Mol. Pharm. 2008, 73, 1225-1234. [CrossRef] [PubMed]

48. Morera, E.; De Petrocellis, L.; Morera, L.; Moriello, A.S.; Nalli, M.; Di Marzo, V.; Ortar, G. Synthesis and biological evaluation of [6]-gingerol analogues as transient receptor potential channel TRPV1 and TRPA1 modulators. Bioorganic Med. Chem. Lett. 2012, 22, 1674-1677. [CrossRef] [PubMed]

49. Riera, C.; Menozzi-Smarrito, C.; Affolter, M.; Michlig, S.; Munari, C.; Robert, F.; Vogel, H.; Simon, S.; Le Coutre, J. Compounds from Sichuan and Melegueta peppers activate, covalently and non-covalently, TRPA1 and TRPV1 channels. Br. J. Pharm. 2009, 157, 1398-1409. [CrossRef]

50. Karashima, Y.; Damann, N.; Prenen, J.; Talavera, K.; Segal, A.; Voets, T.; Nilius, B. Bimodal Action of Menthol on the Transient Receptor Potential Channel TRPA1. J. Neurosci. 2007, 27, 9874-9884. [CrossRef]

51. Alpizar, Y.A.; Gees, M.; Sánchez, A.; Apetrei, A.; Voets, T.; Nilius, B.; Talavera, K. Bimodal effects of cinnamaldehyde and camphor on mouse TRPA1. Pflügers Arch. 2012, 465, 853-864. [CrossRef] [PubMed]

52. Saghy, E.; Payrits, M.; Biro-Suto, T.; Skoda-Foldes, R.; Szanti-Pinter, E.; Erostyak, J.; Makkai, G.; Setalo, G.; Kollar, L.; Koszegi, T.; et al. Carboxamido steroids inhibit the opening properties of transient receptor potential ion channels by lipid raft modulation. J. Lipid Res. 2018, 59, 1851-1863. [CrossRef] [PubMed]

53. Viana, F. TRPA1 channels: Molecular sentinels of cellular stress and tissue damage. J. Physiol. 2016, 594, 4151-4169. [CrossRef] [PubMed]

54. Gracheva, E.O.; Ingolia, N.T.; Kelly, Y.M.; Cordero-Morales, J.F.; Hollopeter, G.; Chesler, A.T.; Sánchez, E.E.; Pérez, J.C.; Weissman, J.S.; Julius, D.; et al. Molecular basis of infrared detection by snakes. Nature 2010, 464, 1006-1011. [CrossRef]

55. Kang, K.; Panzano, V.C.; Chang, E.C.; Ni, L.; Dainis, A.M.; Jenkins, A.M.; Regna, K.; Muskavitch, M.A.T.; Garrity, P.A. Modulation of TRPA1 thermal sensitivity enables sensory discrimination in Drosophila. Nature 2011, 481, 76-80. [CrossRef]

56. Saito, S.; Nakatsuka, K.; Takahashi, K.; Fukuta, N.; Imagawa, T.; Ohta, T.; Tominaga, M. Analysis of Transient Receptor Potential Ankyrin 1 (TRPA1) in Frogs and Lizards Illuminates Both Nociceptive Heat and Chemical Sensitivities and Coexpression with TRP Vanilloid 1 (TRPV1) in Ancestral Vertebrates. J. Biol. Chem. 2012, 287, 30743-30754. [CrossRef]

57. Laursen, W.J.; Anderson, E.O.; Hoffstaetter, L.J.; Bagriantsev, S.N.; Gracheva, E.O. Species-specific temperature sensitivity of TRPA1. Temperature 2015, 2, 214-226. [CrossRef]

58. Cordero-Morales, J.F.; Gracheva, E.O.; Julius, D. Cytoplasmic ankyrin repeats of transient receptor potential A1 (TRPA1) dictate sensitivity to thermal and chemical stimuli. Proc. Natl. Acad. Sci. USA 2011, 108, E1184-E1191. [CrossRef]

59. Zurborg, S.; Yurgionas, B.; Jira, J.A.; Caspani, O.; Heppenstall, P.A. Direct activation of the ion channel TRPA1 by $\mathrm{Ca}^{2+}$. Nat. Neurosci. 2007, 10, 277-279. [CrossRef]

60. Ciesielski, F.; Davis, B.; Rittig, M.; Bonev, B.B.; O'Shea, P. Receptor-Independent Interaction of Bacterial Lipopolysaccharide with Lipid and Lymphocyte Membranes; the Role of Cholesterol. PLoS ONE 2012, 7, e38677. [CrossRef]

61. Ciesielski, F.; Griffin, D.C.; Rittig, M.; Moriyón, I.; Bonev, B.B. Interactions of lipopolysaccharide with lipid membranes, raft models-A solid state NMR study. Biochim. Biophys. Acta (BBA) Biomembr. 2013, 1828, 1731-1742. [CrossRef] [PubMed]

62. Lafont, F.; Van Der Goot, G. Bacterial invasion via lipid rafts. Cell. Microbiol. 2005, 7, 613-620. [CrossRef] [PubMed]

63. Varshney, P.; Yadav, V.; Saini, N. Lipid rafts in immune signalling: Current progress and future perspective. Immunology 2016, 149, 13-24. [CrossRef] [PubMed]

64. Ruysschaert, J.-M.; Lonez, C. Role of lipid microdomains in TLR-mediated signalling. Biochim. Biophys. Acta (BBA) Biomembr. 2015, 1848, 1860-1867. [CrossRef] [PubMed]

65. Brown, D.A.; Rose, J.K. Sorting of GPI-anchored proteins to glycolipid-enriched membrane subdomains during transport to the apical cell surface. Cell 1992, 68, 533-544. [CrossRef]

66. Schmitz, G.; Orsó, E. CD14 signalling in lipid rafts: New ligands and co-receptors. Curr. Opin. Lipidol. 2002, 13, 513-521. [CrossRef]

67. Lopez-Requena, A.; Boonen, B.; Van Gerven, L.; Hellings, P.W.; Alpizar, Y.A.; Talavera, K. Roles of neuronal TRP channels in neuroimmune interactions. In Neurobiology of TRP Channels, 2nd ed.; Emir, T.L.R., Ed.; CRC Press: Boca Raton, FL, USA, 2017; pp. 277-294. 
68. Shi, X.Q.; Lim, T.; Lee, S.; Zhao, Y.Q.; Zhang, J. Statins alleviate experimental nerve injury-induced neuropathic pain. Pain 2011, 152, 1033-1043. [CrossRef]

69. Kilsdonk, E.P.C.; Yancey, P.G.; Stoudt, G.W.; Bangerter, F.W.; Johnson, W.J.; Phillips, M.; Rothblat, G.H. Cellular Cholesterol Efflux Mediated by Cyclodextrins. J. Boil. Chem. 1995, 270, 17250-17256. [CrossRef]

70. Yancey, P.G.; Rodrigueza, W.V.; Kilsdonk, E.P.; Stoudt, G.W.; Johnson, W.J.; Phillips, M.C.; Rothblat, G.H. Cellular cholesterol efflux mediated by cyclodextrins: Demonstration of kinetic pools and mechanism of efflux. J. Boil. Chem. 1996, 271, 16026-16034. [CrossRef]

71. Christian, A.E.; Haynes, M.P.; Phillips, M.C.; Rothblat, G.H. Use of cyclodextrins for manipulating cellular cholesterol content. J. Lipid Res. 1997, 38, 2264-2272.

72. Mahammad, S.; Parmryd, I. Cholesterol Depletion Using Methyl- $\beta$-cyclodextrin. In Methods in Membrane Lipids, Owen; Owen, D.M., Ed.; Springer: New York, NY, USA, 2014; pp. 91-102.

73. Sohn, J.; Hang, L.; Madalyn, R.F.; Rocky, S.T. Influence of cholesterol/caveolin-1/caveolae homeostasis on membrane properties and substrate adhesion characteristics of adult human mesenchymal stem cells. Stem Cell Res. Ther. 2018, 9, 86. [CrossRef] [PubMed]

74. Zidovetzki, R.; Levitan, I. Use of cyclodextrins to manipulate plasma membrane cholesterol content: Evidence, misconceptions and control strategies. Biochim. Biophys. Acta (BBA) 2007, 1768, 1311-1324. [CrossRef] [PubMed]

75. Goni, F.M.; Alonso, A. Sphingomyelinases: Enzymology and membrane activity. FEBS Lett. 2002, 531, 38-46. [CrossRef]

76. Schuchman, E.H. Acid sphingomyelinase, cell membranes and human disease: Lessons from Niemann-Pick disease. FEBS Lett. 2009, 584, 1895-1900. [CrossRef]

77. Grynkiewicz, G.; Poenie, M.; Tsien, R.Y. A new generation of $\mathrm{Ca}^{2+}$ indicators with greatly improved fluorescence properties. J. Boil. Chem. 1985, 260, 3440-3450.

(C) 2020 by the authors. Licensee MDPI, Basel, Switzerland. This article is an open access article distributed under the terms and conditions of the Creative Commons Attribution (CC BY) license (http://creativecommons.org/licenses/by/4.0/). 